\title{
DESIGN AND FABRICATE A METERING DEVICE OF VACUUM SEEDER TO SUIT EGYPTIAN COTTON
}

\author{
YOSRY ABD EL-KAWY SH. EL-SAYAD
}

Agric.Eng. Res. Institute, ARC, Dokki. Giza. Egypt.

(Manuscript received 11 November 2012)

\begin{abstract}
The objective of this study was to develop a design, fabricate and test a metering device to suit hill-dropped for Egyptian cotton cultivar a precision planting. The developed metering device was fabricated from local materials Stainless Steel 304. Tests were conducted at an indoor field facility under different operational parameters. These were three seed plates with four level of forward speeds $(2.2,3.1,4.3$ and $5.0 \mathrm{~km} / \mathrm{h})$. Measurements were taken for average plant number per hill, coefficient of variation of plant number per hill, mean hill distance, coefficient of variation of hill distance, seed miss index, seed multiple index, quality of feed index, precision in spacing, and plant scattering along the length of the row was investigated under field conditions. The economic assessment of the use a vacuum precision planter, rather than traditional method. Results indicated that the optimum values of the mean hill distance of $16.7 \mathrm{~cm}$, mean plant number per hill ranged from 2 to 3 seeds, seed miss index $10 \%$, seed multiple index of zero\%, quality of feed index of $90 \%$, precision in spacing of $19 \%$ were obtained with the seed plate (1).The statistical analysis showed that the most desirable conditions in terms of operating developed metering device were obtained at $3.1 \mathrm{~km} / \mathrm{h}$ forward speed for the seed plate (1).
\end{abstract}

\section{INTRODUCTION}

In Egypt, the cotton precision planting are still very limited. The total cultivated area of cotton is about more than 300,000 feddan. This area is going to reach 1,000,000 feddan (Agriculture and Development Strategy 2030). The farmers planting cotton crop in the groups of 5-10 seeds per hill manual's given the weakness of the fetus and its inability to penetrate the soil, especially heavy clay soil. The disadvantage of this manual sowing are, variable distance between hill and variable number of seeds per hill, that result in variable plant lengths. Hence, an optimum plant population with optimum spacing between plants could not be achieved in farmers'fields. The imported precision vacuum planter suffered from some of problems for Egyptian cotton varieties. This attributes to the differences of physical properties of Egyptian cotton crop, leading to the miss index for seeds in 
the row. So it is a need a new design of metering device with number of cells and it size commensurate with the characteristics of Egyptian cotton varieties. This is in addition to the imported precision planter does not sowing the cotton seeds in hill dropping, which reflected positively on all mechanical bicking and production. Many studies have been conducted in order to evaluate the performance of precision seeders. These mostly experimental studies, reveal information about how the metering systems of precision seeders performs in the laboratory or field. Studies mostly focus on the behavior of the vacuum pressure applied to the seed chamber, which is the most common metering system in precision seeder. In a recent study, Karayel and Özmerzi (2004) examined the effects of different forward speeds on hill dropping melon (Cucumis melo) and watermelon (Citrullus lanatus) seeds with reference to hill dropping uniformity. They used three different seed plates at the forward speeds of $0.5,1.0,1.5$, and $2.0 \mathrm{~m}^{-s^{-1}}\left(1.8,3.6,5.4\right.$, and $\left.7.2 \mathrm{~km} . \mathrm{h}^{-1}\right)$. They found that mean hill distance was not affected by forward speed and seed plates, but mean seed number in hill was affected. The coefficients of variation of hill distance and seed number in hill increased as forward speed increased for both seeds. The scattering distance ratios for forward speeds of $20 \%$ to $30 \%$. Ryu and Kim (1998) reported that the lower the scattering distance ratio, the better performance of hill dropping i.e. scattering distance ratio of $100 \%$ indicates drill plantings. Scattering distance ratios less than $30 \%$ are known to be good enough for precision hill dropping. Karayel et. al. (2004) created a generalized model for predicting the vacuum pressure. They used $3.5 \mathrm{~mm}$ hole diameter for cotton seeds and obtained a highest quality of feed index of $92.2 \%$ at $3 \mathrm{kpa}$ vacuum pressure. Arzu and Adnan (2007) verified optimum levels of the vacuum pressure on the seed plate, the diameter of seed holes and the peripheral speed of the seed plate for cotton seeds. They found that the optimum levels of the vacuum pressure and the diameter of seed holes were $5.5 \mathrm{kPa}$ and $3 \mathrm{~mm}$, respectively. No optimum value was obtained for the peripheral speed of the seed plate for cotton seeds. Moreover, Singh et al (2005) evaluate the seed metering device of pneumatic planter for cotton seeds used four parameters. Conical entrance angle, multiple index, miss index, quality of feed index and precision in spacing. They found that the conical entrance angle $\left(120^{\circ}\right)$ gave superior performance at all speeds and operating pressure. Lower miss indices were observed at higher pressures and lower speeds. Also lower multiple indices at lower pressures and higher speeds. The metering system produced superior results of a feed index of $94.7 \%$ at a speed of $0.42 \mathrm{~m} / \mathrm{s}(1.5 \mathrm{~km} / \mathrm{h})$ and a vacuum pressure of 2 $\mathrm{kPa}$. Many studies have been conducted in order to determine the influence of sowing time on yield. Hallikeri et. al., (2008) studies the influence of sowing time on growth, 
seed cotton yield and fibre quality of Bt-cotton. They found that sowing time had a significant influence on seed cotton yield. Manimehalai and Viswanathan (2006) evaluated some physical properties such as dimensions (length, thickness, width), sphericity and moisture content for cotton seeds. The values of the sphericity were not significantly different with respect to the mass ranges and varied between 0.64 and 0.67. Özarslan (2002) evaluated some physical properties of delinted and bare cotton seed as a function of moisture content. The average length, width, and thickness of seeds ranged from 9.02 to $9 \cdot 19,4.70$ to 4.86 and 4.25 to $4.45 \mathrm{~mm}$ as the moisture content (d.b.) increased from 8.33 to $13.78 \%$, respectively. Sheikh and Gadir (2004) evaluated the mechanical sowing of medium staple cotton seed. Results indicated a complete failure of mechanical sowing operation with mechanically delinted seeds. However, mechanical sowing of cotton seeds would be economically feasible with the use of chemical delinted cotton seeds. Mechanical sowing of cotton with chemically delinted seeds saved a lot of time( $9 m a n-h / h a)$ that reduced about $40 \%$ of the amount of seed rate in comparison with manual sowing method. Deyong et. al. (2010) examined the performance of a modified vacuum seeder for hill drop sowing of sesame (Sesamum indicum L.) following wheat (Triticum aestivum) for notill and reduced tillage farming. A fluted coulter and double disc-type furrow opener were mounted on each unit of a common vacuum seeder. A seed plate modified to achieve hill-dropping of seeds was used in the metering mechanism of the seeder. Most of the metering devices for the imported a precision vacuum planters' is not suitable for hill dropping of cotton seeds. Therefore, the main objective of the present study , design , fabricate and test a metering device to suit hill- dropped for Egyptian cotton seeds.

\section{MATERIALS AND METHODS}

\section{Delinting cotton seeds}

The cotton seeds are removed from kapas the fruiting body which has both seed and lint. In the separated seed, seed coat will have hairy outgrowth and this is the genetic characteristic feature of the seed. The seeds were delinted by using acid by taking one $\mathrm{kg}$ of the cotton (fuzzy seeds) in a plastic bucket, add concentration $\mathrm{H}_{2} \mathrm{SO}_{4}$ (Not less than $95 \%$ ) at the rate of $150 \mathrm{~cm} / 5 \mathrm{~kg}$ of seeds. While additions it should be constant stirring by using wooden stick for 2-3 minutes to facilitate uniform coverage and better treatment effect. After 3 minutes all seeds will turn into coffee brown in colour. Wash the seeds immediately for 4-5 times with cold water until the acid nature of the seed is removed and care should be taken while washingwhere, the improper washing will affect the viability of the seed. After thorough washing the entire seed 
should be placed in water in 1: 10 ratio to remove floaters. To complete removal of acid seeds can be dipped in $0.5 \%$ calcium chloride solution for $10-15$ minutes, and the sinkers seeds can be used for sowing purpose.Samples of cotton seeds were taken before and after delinting, in order to germinate for each of them in the laboratory.

\section{Physical characteristics of tested cotton seeds after delinting.}

\section{Moisture content for seed sample}

The moisture content of cotton seed was determined using a gravitational method (ASAE Standard, 1994) using the following equation.

$$
\text { Mositure Content }=\frac{\text { Mass of samples }- \text { Mass of dry Samples }}{\text { Mass of dry Samples }} \times 100
$$

\section{Cotton seed linear dimensions.}

Three linear dimensions of cotton seed were measured using a digital caliper with a sensitivity of $0.01 \mathrm{~mm}$. These were length, thickness and width. Three samples were taken to determine the linear dimensions, each sample of random 100 seeds.

\section{The degree of sphericity.}

The degree of sphericity were calculated using Mohsenin equation (Mohsenin, 1986).

$$
\phi=\frac{(L W T)^{(1 / 3)}}{L} \times 100
$$

Where:

$$
\begin{aligned}
\phi & =\text { the degree of sphericity }, \%, \\
\mathrm{~L} & =\text { length of seed }, \mathrm{mm}, \\
\mathrm{W} & =\text { width of seed }, \mathrm{mm}, \text { and }
\end{aligned}
$$

$\mathrm{T}=$ thickness of seed, $\mathrm{mm}$.

\section{Angle of repose}

Angle of repose was very essential for designing the seed box of our machine to insure the continuous flow of cotton seeds. For determination of this angle an apparatus was used as is shown in (Fig. 1), in which the seed cotton were left to flow freely and gently through a cylindrical tube to the base. The leg opposite and average of three values for leg adjacent were measured. The test was repeated three times and the average was measured by:

$$
\theta=\arctan \frac{\text { leg opposite }}{\text { leg adjacent }}
$$

Where: $\theta$ is the angle of repose, degree. 


\section{Geometric mean diameter.}

The geometric mean diameter of cotton seeds was very essential for designing the hole diameter on the seed plate. The geometric mean diameter ( $\mathrm{dg}$ ) was determined from the samples of linear dimensions of cotton seeds using Singh et al (2005): $\quad d g=(L W T)^{(1 / 3)}, \mathrm{mm}$

Table 1. Physical characteristics of cotton seeds.

\begin{tabular}{lccccc}
\hline \multicolumn{1}{c}{ Item } & Sample1 & $\begin{array}{c}\text { Sample } \\
\text { 2 }\end{array}$ & $\begin{array}{c}\text { Sample } \\
\mathbf{3}\end{array}$ & $\begin{array}{c}\text { Mea } \\
\boldsymbol{n}\end{array}$ & SD \\
\hline & \multicolumn{2}{c}{ cotton seed properties } & & & \\
Linear dimensions & & & & & \\
Length, mm & $8.52^{*}$ & $8.52^{*}$ & $8.62^{*}$ & 8.55 & 0.54 \\
Width, mm & $5.27^{*}$ & $5.24^{*}$ & $5.21^{*}$ & 5.24 & 0.39 \\
Thickness, mm & $4.66^{*}$ & $4.61^{*}$ & $4.63^{*}$ & 4.63 & 0.30 \\
Geometrical mean diameter, mm & $5.94^{*}$ & $5.90^{*}$ & $5.92^{*}$ & 5.91 & 0.02 \\
Sphericity $(\phi), \%$ & $69.72^{*}$ & $69.25^{*}$ & $68.68^{*}$ & 69.22 & 0.50 \\
Moisture content (db), \% & $8.96^{* *}$ & $9.31^{* *}$ & $10.4^{* *}$ & 9.56 & 0.70 \\
Angle of repose , degrees & $25.42^{* *}$ & $28.29^{* *}$ & $30.00^{* *}$ & 27.90 & \\
\hline
\end{tabular}

${ }^{*}$ Average of 100 readings.

**Average of 5 readings.
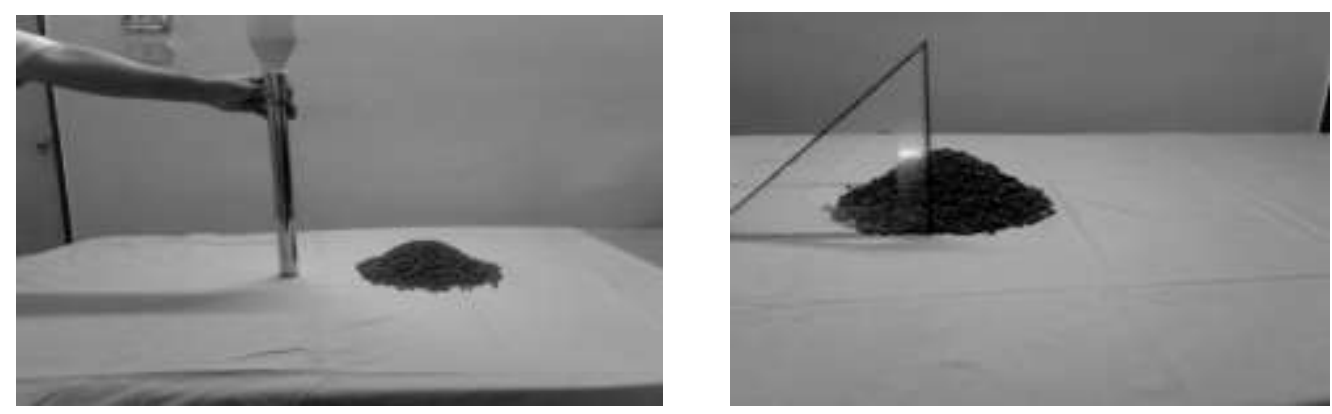

1.Sample of delinted cotton seeds

2. Determination angle of repose

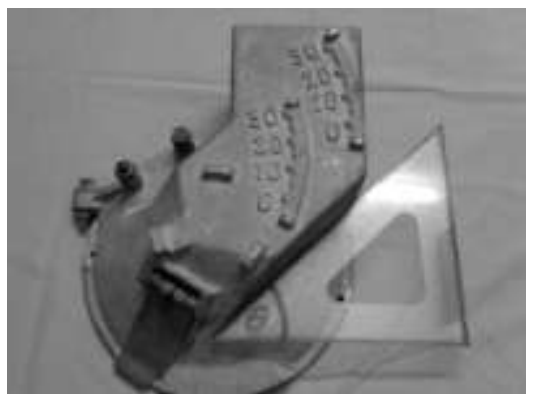

3. Angle of repose at the seed chamber

Fig.1. Determination of angle of repose 


\section{Key parts of a vacuum metering device for cotton seeds.}

The metering device (Fig. 2) consisted of a seed box with a chamber of seed, main shield with air cut-off device. The main shield consists of driving shaft, negative pressure inlet and seed plate. The negative pressure chamber was made around after the ring was fixed to the main shield. Three different types of seed plates (Fig. 3) (outer diameter of $230 \mathrm{~mm}$ ) were fabricated from stainless steel 304 with $20 \mathrm{~mm}$ thickness. The holes in each seed plate were drilled into ( two- three- four holes). The pitch circle diameters of the holes were $210 \mathrm{~mm}$. and $195 \mathrm{~mm}$, respectively. Seed plate is mounted to the drive shaft of the precision vacuum planter as shown in (Fig. 2). All of seed plate had ( 10 ) groups. seed plate 1 had two holes, seed plate 2 had three holes and seed plate 3 had four holes in each hole group, they had total 20,30, 40 holes, respectively (Fig. 3 ). Each of the holes was $3.0 \mathrm{~mm}$ in diameter based on $\leq$

$50 \%$ size of geometric mean diameter for cotton seeds. The entry shape of seed hole of the seed plate was conical entrance angle $\left(120^{\circ}\right)$ Singh et. al. (2005). The seed plate operated in vertical plane and required a vacuum of 50 to 60 mbar to select a seed. The vacuum pressure in the hole was measured using a manometer with an accuracy of 1.0-mbar (100Pa.) under different levels of blower speeds and using the three seed plates.

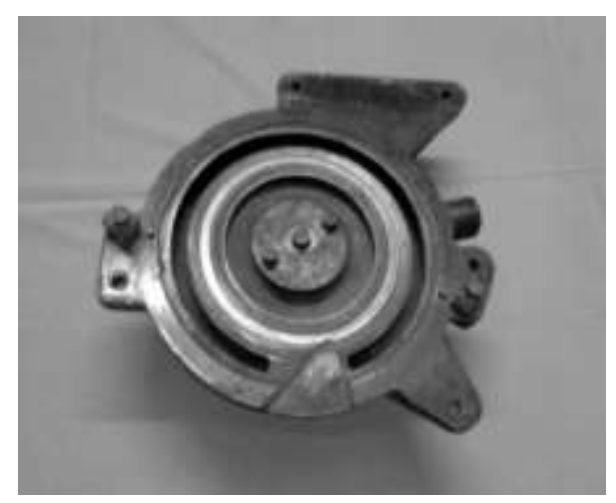

The main shield with air cut-off device

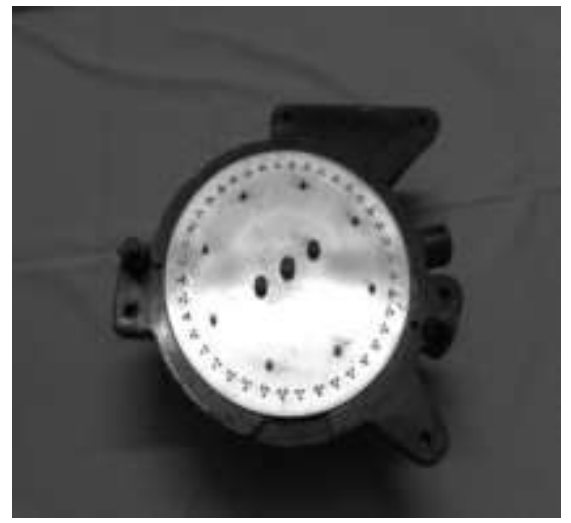

The seed plate inside the shield

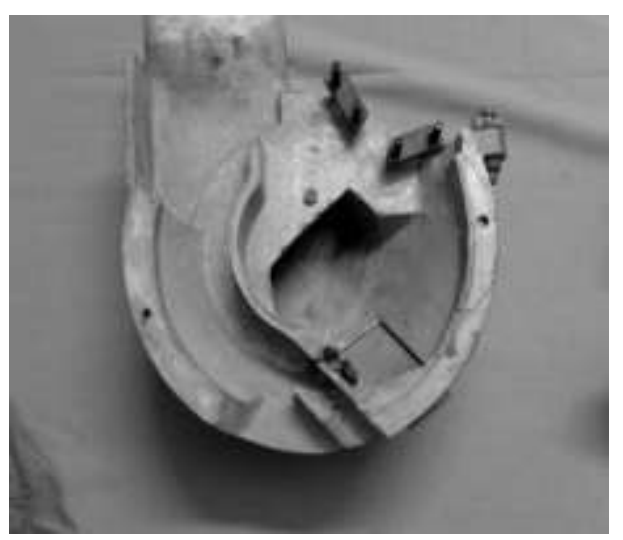

Chamber of seed

Fig.2. Main parts of the investigated precision vacuum planter. 


\section{Experimental field}

Tests under field conditions were carried out using a precision vacuum planter under four levels of forward speeds. The different forward speeds were (2.2, 3.1, 4.3 and $5.0 \mathrm{~km} / \mathrm{h}$ ) and three types of seed plate (Fig.3). However, The specifications of the precision vacuum planter is shown in the (Table 2). The experimental soil was classified as a Clay having $53.32 \%$ clay, $17.63 \%$ silt and $29.05 \%$ sand. The land of experimental area was about 0.5 feddan and located in Rice mechanization center, Meet El-Deeba,Kafer El-Sheikh Governorate, during season 2010-2011.The precision vacuum planter were adjusted to deliver a hill seed at a theoretical seed spacing (nominal seed spacing) of $150 \mathrm{~mm}$ in row with a transmission ratio of 0.65(Fig.4)

\section{Operating speed}

Although, the tractor travel speed was selected according to the gear box, the actual travel speed during tests was measured three times for each nominal speed. It was calculated by recording the distance and time of 10 revolutions of the rear tractor wheels. The actual forward speeds under field conditions were 2.2, 3.1, 4.3, and 5.0 $\mathrm{km} / \mathrm{h}$.

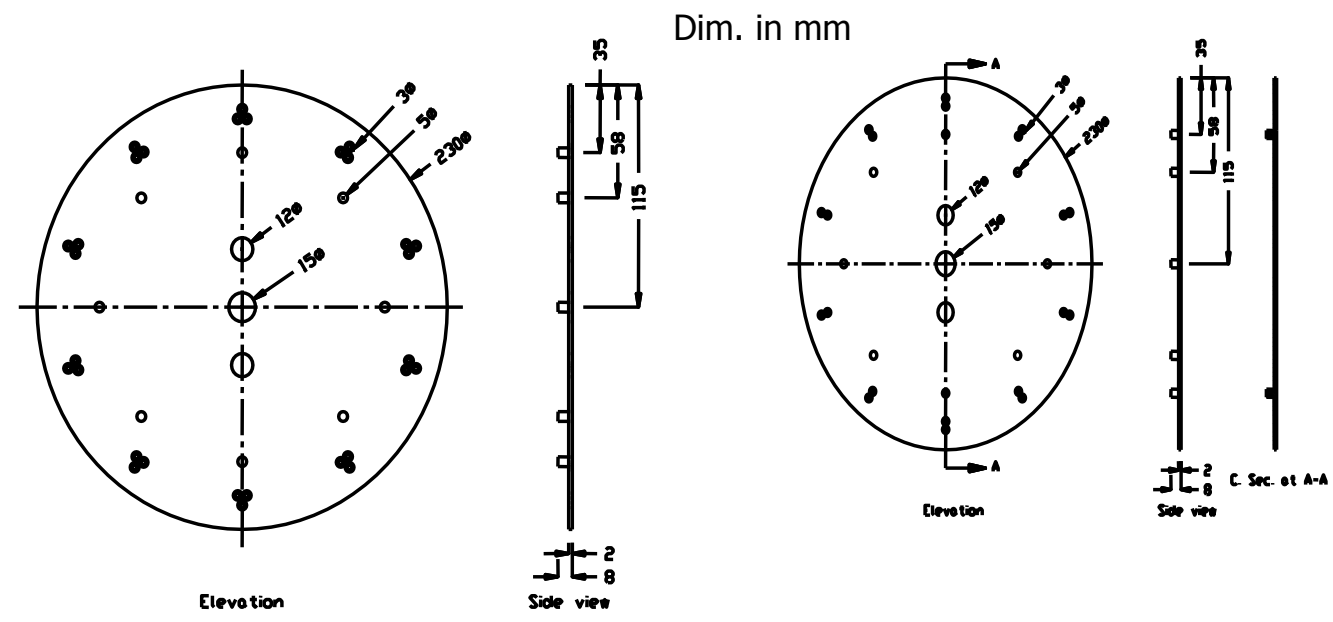

Seed plate 2
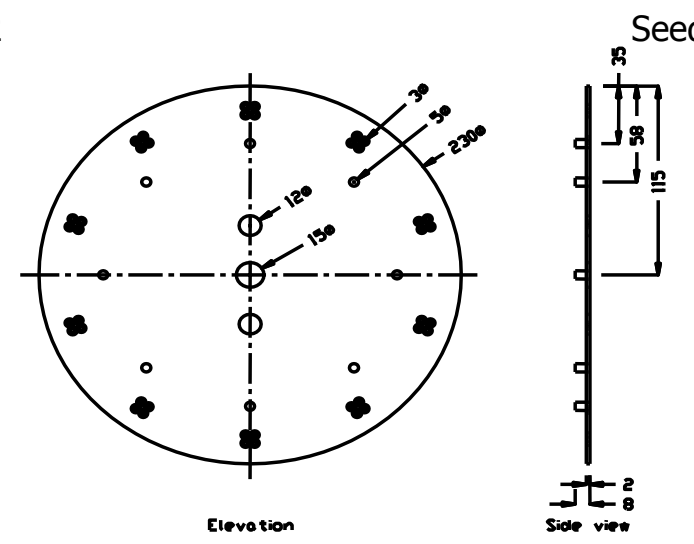

Seed plate 3

Fig. 3. The seed plates for hill dropping of cotton seeds. 


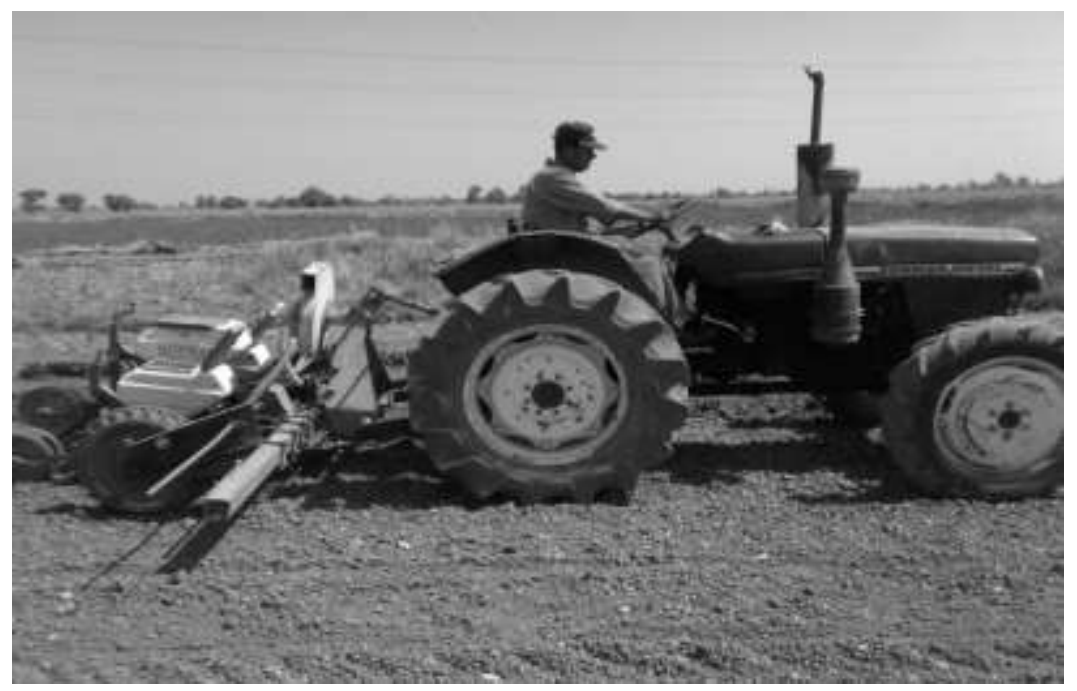

Fig. 4. Yanmar tractor and Koymac precision vacuum planter.

Table 2. The technical specifications of precision vacuum planter.

\begin{tabular}{|l|c|}
\hline Specifications & Characteristic \\
\hline Model & Koymac \\
\hline Country of production & Turkey \\
\hline Planter type & Pneumatic \\
\hline Pneumatic type & Vacuum \\
\hline No. of units & 3 \\
\hline Type of furrow opener & Runner \\
\hline Type of closing device & Rubber material \\
\hline
\end{tabular}

\section{Planting depth}

Although, the planting depth was adjusted to be $40 \mathrm{~mm}$, the actual planting depth was measured by excavating two meters lengths of seed row in each plot and measuring the vertical distance from the center of the seed to the soil surface. The actual planting depth was measured by the vertical distance from soil surface to cotton seeds placed in soil after removing the soil cover.

\section{Hill dropping uniformity}

After the plants emerged ( 16th days following seedling). The hill dropping uniformity was analyzed using the methods described by Ryu and Kim (1998) and by Kachman and Smith (1995). The plant number per hill on the field and hill distances between the hills and the longitudinal and lateral plant distribution from the center line of the row were measured. Position of each plant are defined by $X i, j$ in which 
subscripts $\mathrm{i}$ and $\mathrm{j}$ indicate the jth plant in the $i$ th hill. The center position of the ith hill, $C i$, and hill distance, Sp were computed by:

$\mathrm{C}_{\mathrm{i}}=\frac{\sum_{\mathrm{j}=1}^{\mathrm{n}_{\mathrm{i}}} \mathrm{X}_{\mathrm{i}, \mathrm{j}}}{\mathrm{n}_{\mathrm{i}}}$

$$
\mathrm{S}_{\mathrm{i}}=\mathrm{X}_{\mathrm{c}_{i} \mathrm{i}+1}-\mathrm{X}_{\mathrm{c}_{\mathrm{i}} \mathrm{i}}
$$

where $\mathrm{n}$ is the total number of plants in $i$ th hill. Dispersion of plants can be evaluated by the positions of plants with respect to the hill center.Therfore, position of plants should be expressed with respect to the hill center. The position of a plant with respect to the hill center, SP $i, j$ was computed by the following equation.

$$
S P i_{j} j=\frac{X i_{j} j-C i}{S i}
$$

\section{Measurements and Economic assessment}

\section{Miss index}

Miss index is the percentage of spacing greater than 1.5 times the theoretical spacing ( $\mathrm{X}$ ref) and indicates the percentage of missed seed locations or 'skips'. It was calculated using the following equation:

$$
\text { Miss }=\frac{n_{11}}{N} \times 100
$$

Where:

Miss $=$ miss index,$\%$,

$n_{1}=$ number of measured spacing greater than $1.5 \mathrm{X}$ ref, and

$\mathrm{N}=$ total number of measured spacing.

\section{Multiple index}

The multiple index is the percentage of spacing that are less than or equal to half of the theoretical spacing and indicates the percentage of multiple seed drops. It was determined using the following equation:

$$
\begin{aligned}
& \text { Multi }=\frac{n_{2}}{N} \times 100 \\
& \text { Where: } \\
& \text { Mult } i=\text { multiple index, } \% \text {, and } \\
& n_{2}=\text { number of measured spacing less than or equal to half. }
\end{aligned}
$$

\section{Quality of feed index}

The quality of feed index is the percentage of spacing that are more than half but not more than 1.5 times the set planting distance $X$ ref in $\mathrm{mm}$. The quality of feed 
index is an alternate way of presenting the performance of misses and multiples. It was determined using the following equation:

Quality of feed index,$\%=100-$ (Miss index + Multiple index)

\section{Precision in spacing}

The precision of seed spacing is a measure of the variability (coefficient of variation) in spacing $X$ ref, between seeds after accounting variability due to both multiple and miss indexes.

$\operatorname{Pr}=\frac{S_{2}}{X_{\text {ref }}} \times 100$

Where:

$P r=$ precision in spacing ,\%, and

$S_{2}=$ standard deviation of the measured spacing more than half but not more than 1.5 times the theoretical $\operatorname{spacing}\left(X_{r e f}\right)$ in region (2).

\section{plant scattering}

The plant distribution was analyzed to determine coefficient of variation ( $\mathrm{CV}$ ) of hill spacing according to the following formula:

$C V, \%=\frac{S D \text { of hill spacing }}{\text { Recommended hill spacing }} \times 100$

$S D=\sqrt{(\text { hill spacing-Recommended hill spacing })^{2}}$

Where :

$S D$ is the standard deviation .

\section{Total Cost (Tc)}

The total costs (Tc) were estimated using equation of Oida (1997) according to 2012 price levels.

$T C=\frac{\left\{\left[\frac{p-s}{Y}+\left[\frac{p+s}{2} \cdot \frac{i}{100}+\langle .02 P\rangle\right]+\left[\left(\frac{P . r}{Y}\right)+(\text { fP.F.n })+(\text { Oc.C.n })+(\text { N.L.n })\right]\right]\right\}}{n}$

Where:

$\mathrm{TC}=$ Total cost, $\mathrm{LE} / \mathrm{h}$,

$\mathrm{P}=$ Purchase price, $\mathrm{LE}$,

$=80000 \mathrm{LE}$ for tractor and $90000 \mathrm{LE}$ for precision vacuum planter,

$\mathrm{S}=$ Salvage value, $\mathrm{LE}$,

$=0.68(0.920)^{Y} * P \quad$ for tractor 


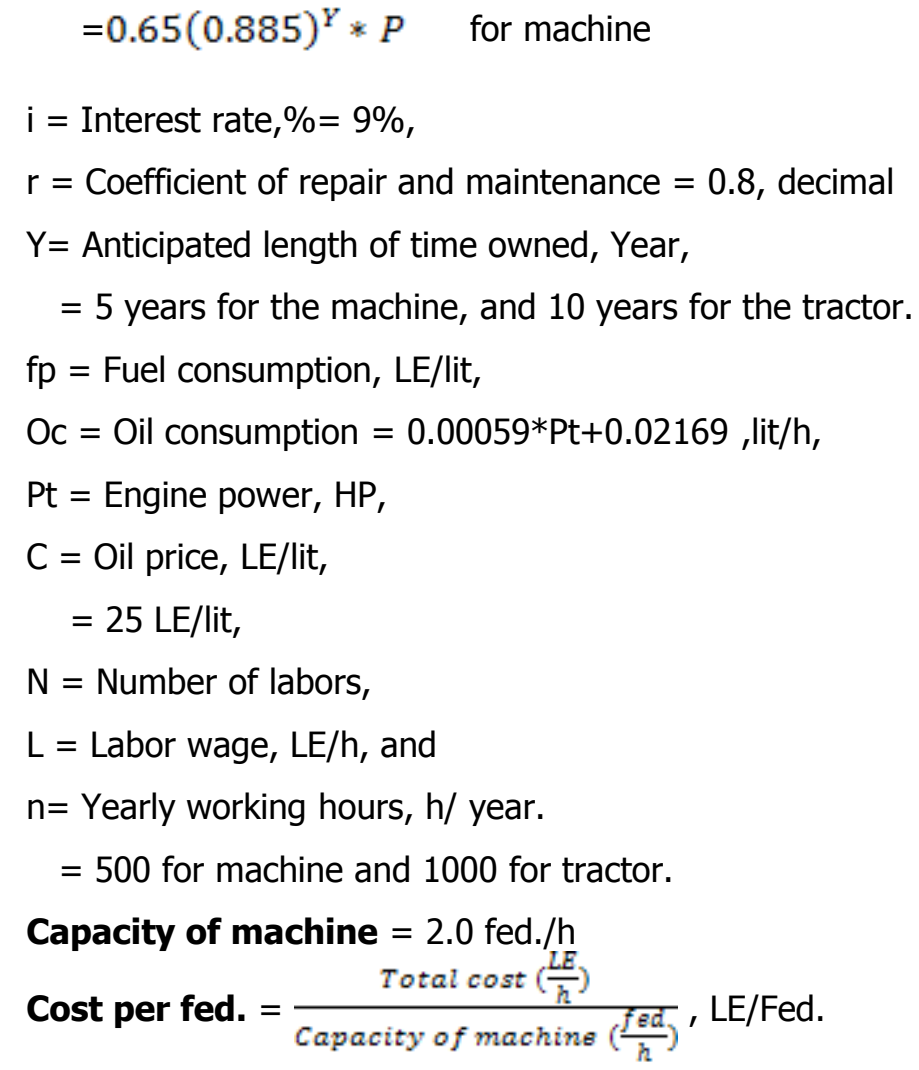

Custom work charge $=$ Cost per fed. Plus $50 \%$

\section{RESULTS AND DISCUSSION}

\section{Hill dropping uniformity at different forward speeds}

Table 3 shows the mean hill distance and the mean seed number in hill at different forward speeds for the developed metering device. The highest values of the mean hill distance were obtained with the seed plate (3). However, the seed plate (1)produced the lowest values of the mean hill distance. The closest values of mean hill distance in relation to the nominal hill distance $(15 \mathrm{~cm})$ were obtained with the seed plate (1). On the other hand, the difference between the nominal and the mean hill distance with three seed plates does not exceed by more than $13 \%$. These results duo to that the hole diameter of $3.0 \mathrm{~mm}$ is equal to $50 \%$ of the geometric mean diameter $(2.96 \mathrm{~mm})$ of cotton seeds, which resulting a highest values of hill distance. The relation between the mean hill distance with the different forward speeds is shown in Table 5. It indicates that the mean hill distance increased as the forward speed increased for the three seed plates. In a comparison between the nominal and the mean hill distance at different forward speeds, the $3.1 \mathrm{~km} / \mathrm{h}$ forward speed resulted in the closest values of the mean hill distance as a compared with $2.1,4.3$, and $5.3 \mathrm{~km} / \mathrm{h}$ forward speeds for the three seed plates. These results are in agreement with previous 
finding by Karayel and Özmerzi (2002). The highest values of the mean hill distance were obtained with the seed plate (3). Table 3 shows the mean seed number at different forward speeds for the developed metering device. Mean seed number in hill decreased as forward speed increased for hill dropping with all seed plates. According to mean seed number in hill, seed plate 1 can be advised for hill dropping of 2-3 seeds, seed plate 2 for hill dropping 3-4 seeds, and seed plate 3 for hill dropping 4-5 seeds at the forward speed of 2.2 and $3.1 \mathrm{~km} / \mathrm{h}$.

\section{The seed miss index}

Fig. 5 shows the effect of the forward speed on the seed miss index for the developed metering device. It shows that the lowest values of the seed miss indices were obtained at 2.2 and $3.1 \mathrm{~km} / \mathrm{h}$ followed by 4.3 , and $5.0 \mathrm{~km} / \mathrm{h}$ forward speeds, respectively. This result due to that the seed plate at high disc speed does not get enough time to pick up seeds, which resulting in higher miss indices. This result is in agreement with the previous finding by Chhinnan et. al., (1975) and Karayel and Ozmerzi (2002).

\section{The seed multiple index}

Fig. 6 shows the seed multiple index with three seed plates for the developed metering device. The highest values of the seed multiple indices were obtained with the seed plate (1) at different levels of the forward speed. However, the lowest values of the seed multiple indices were obtained with the seed plate(3) at different levels of the forward speed. The seed multiple indices decreased by $50 \%$ as forward speed increased from 2.2 to $5.0 \mathrm{~km} / \mathrm{h}$. These results due to that the seed plate at low disc speed get enough time to pick up more than one seed, which resulting a higher in multiple indices. These results also are in agreement with previous finding by Barut and Ozmerzi (2004) and Singh et al (2005). Results of the seed multiple index with the forward speed indicates the lowest values were obtained at $3.1 \mathrm{~km} / \mathrm{h}$ forward speed. However, there was none potential change in the seed multiple indices between 4.3 and $5.0 \mathrm{~km} / \mathrm{h}$ forward speeds Fig. 6 .

\section{The quality of feed index}

Fig. 7 shows the effect of the forward speed on the quality of feed index for the developed metering device. It shows that the highest values of the quality of feed index were obtained at 2.2 and $3.1 \mathrm{~km} / \mathrm{h}$ forward speed.. These results may be attributed to that the increasing ratio in the seed miss index by increasing forward speed equal the decreasing ratio in the seed multiple index (Figs. $5 \& 6$ ).

\section{The precision in spacing}

The precision in spacing in relation to different levels of forward speeds for the developed metering device are shown in Fig.8. It indicates that, Results of the precision 
in spacing with different forward speeds Fig. 7 showed that the forward speed of 2.2 and $3.1 \mathrm{~km} / \mathrm{h}$ gave the lowest values of the precision in spacing. However, there was none potential difference in the precision in spacing between 4.3 , and $5.0 \mathrm{~km} / \mathrm{h}$ forward speeds. This is due to that the highest values of the quality of feed index were obtained at 2.1 and $3.1 \mathrm{~km} / \mathrm{h}$ forward speed. However, there are no changes in the quality of feed indices between 4.3 and $5.3 \mathrm{~km} / \mathrm{h}$ forward speeds for the developed metering device Fig. 7.

\section{Plant scattering at different forward speeds}

Table. 3 shows the effect of the forward speed on the plant distribution (coefficient of variation ) for the developed metering device. It shows that plant scattering of forward speed of 2.2 to $5.0 \mathrm{~km} / \mathrm{h}$ was 11.7 to $24.6 \%$ for three seed plates, indicating a good uniform distribution of seeds for hill dropping for the developed metering device. These results are in agreement with previous findings by Ryu and Kim (1998) reported that scattering distance less than 30\% are known to be good enough for precision hill dropping.

\section{Operational data of vacuum precision planter and manual method for cultivation cotton seeds.}

Total cost for cultivation cotton seeds by vacuum precision planter and manual method are shown in Table 4. Total cost for cultivation cotton seeds by developed vacuum precision planter was $69.3 \mathrm{LE} / \mathrm{fed}$., which is about $65 \%$ lower than that used with manual sowing method. The required average time to use a precision vacuum planter to sowing one feddan of cotton seeds was 0.5 machine - $\mathrm{h} /$ fed.. However, manual sowing required an average time 12 man $-\mathrm{h} /$ fed., which is about 24 times the average time requirement of planter sowing. The use of planter saved about $5.0 \mathrm{~kg}$ of cotton seeds, which is about $38 \%$ lower than that used with manual sowing method. These results are in agreement with previous findings by Sheikh, and Gadir( 2004). 
Table 3. Hill dropping uniformity of precision vacuum planter under different forward speeds using cotton seeds.

\begin{tabular}{|c|c|c|c|c|}
\hline $\begin{array}{c}\text { Forward } \\
\text { speed , } \mathrm{Km} / \mathrm{h}\end{array}$ & $\begin{array}{c}\text { Mean hill } \\
\text { distance ,cm }\end{array}$ & $\begin{array}{c}\text { Mean seed } \\
\text { no. in hill }\end{array}$ & $\begin{array}{c}\text { cv of hill } \\
\text { distance }, \%\end{array}$ & $\begin{array}{c}\text { CV of seed } \\
\text { no. in hill ,\% }\end{array}$ \\
\hline \multicolumn{5}{|c|}{ Seed pate 1} \\
\hline 2.2 & 16.45 & 2.05 & 14.2 & 33.5 \\
\hline 3.1 & 16.35 & 2.1 & 19.8 & 30.5 \\
\hline 4.3 & 16.85 & 1.85 & 24.1 & 31.7 \\
\hline 5.0 & 17.35 & 1.65 & 24.5 & 35.6 \\
\hline \multicolumn{5}{|c|}{ Seed pate 2} \\
\hline 2.2 & 16.75 & 3.3 & 24.6 & 27.9 \\
\hline 3.1 & 16.65 & 3.15 & 20.6 & 33.02 \\
\hline 4.3 & 17.55 & 2.9 & 20.4 & 33.4 \\
\hline 5.0 & 17.9 & 2.7 & 18.7 & 29.7 \\
\hline \multicolumn{5}{|c|}{ Seed pate 3} \\
\hline 2.2 & 18.2 & 4.6 & 23.6 & 17.8 \\
\hline 3.1 & 18.15 & 4.3 & 16.4 & 18.6 \\
\hline 4.3 & 18.4 & 4.05 & 11.7 & 18.7 \\
\hline 5.0 & 18.15 & 3.75 & 17.5 & 19.1 \\
\hline
\end{tabular}



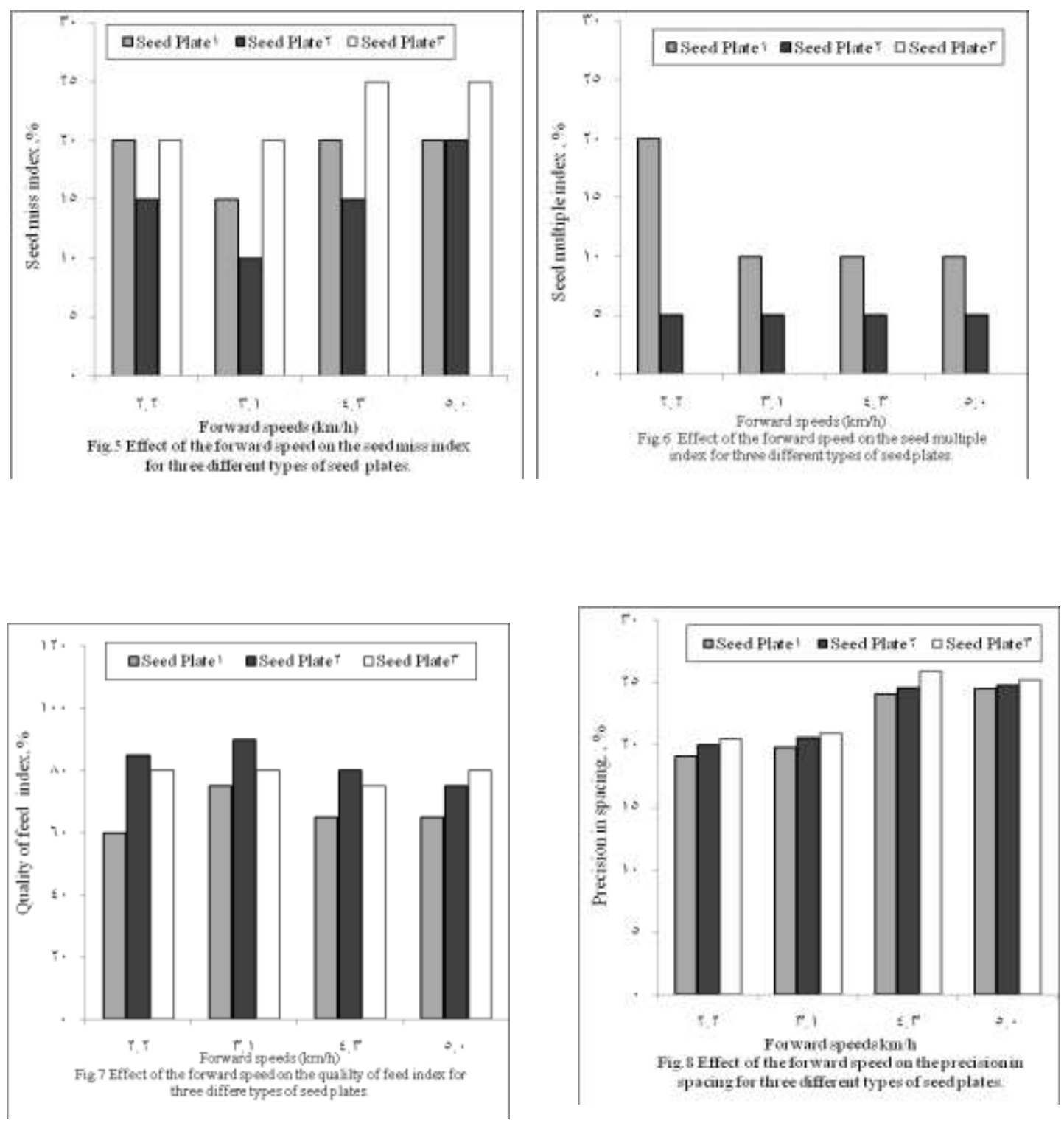
Table 4. Total cost for cultivation cotton seeds by vacuum precision planter and manual method.

\begin{tabular}{|l|c|c|}
\hline \multirow{2}{*}{ Item } & \multicolumn{2}{|c|}{ Sowing method } \\
\cline { 2 - 3 } & vacuum precision planter & Manual method \\
\hline Total hours required for fed,h/fed. & 0.5 & 4 labor* $3 \mathrm{~h}=12$ \\
\hline Total cost, LE/h. & 92.4 & 5 \\
\hline Capacity of machine, fed./h & 2.0 & 0.042 \\
\hline Cost per fed., LE/fed. & 46.2 & 200 \\
\hline Custom work charge,LE/fed. & 69.3 & 200 \\
\hline Amount of seeds/fed.(kg) & 5 & 8 \\
\hline
\end{tabular}

\section{SUMMARY AND CONCLUSION}

Results of this study could be summarized as follows:

-The highest values of the mean hill distance were obtained with the three seed plates at $5.0 \mathrm{~km} / \mathrm{h}$ forward speed. However, the lowest values of the mean hill distance were obtained with the three seed plates at $3.1 \mathrm{~km} / \mathrm{h}$ forward speed for the developed metering device.

-According to mean seed number in hill, seed plate (1) can be advised for hill dropping of 2-3 seeds, seed plate 2 for hill dropping 3-4 seeds, and seed plate 3 for hill dropping 4-5 seeds at the forward speed of $3.1 \mathrm{~km} / \mathrm{h}$.

-The lowest values of the seed miss indices were obtained with the $3.1 \mathrm{~km} / \mathrm{h}$ forward speed for three seed plates .

-The lowest values of the seed multiple indices were obtained with the $3.1 \mathrm{~km} / \mathrm{h}$ forward speed for three seed plates .

-The highest values of the quality of feed indices were obtained at $3.1 \mathrm{~km} / \mathrm{h}$ forward speed with the seed plate (2).

- The lowest values of the precision in spacing were obtained with the 2.2 and $3.1 \mathrm{~km} / \mathrm{h}$ forward speeds with the three seed plates.

-plant scattering of forward speed of 2.2 to $5.0 \mathrm{~km} / \mathrm{h}$ was less than $30 \%$ for three seed plates.

-Total cost for cultivation cotton seeds by developed vacuum precision planter was 69.3 LE/fed., which is about $65 \%$ lower than that used with manual sowing method. 


\section{RECOMMENDATION}

-Physical characteristics of tested cotton seeds showed that the average value of the hole diameter on seed plate equal to $3.0 \mathrm{~mm}$.

- Field tests showed that the most favorable conditions in terms of operating developed metering device will be $3.1 \mathrm{~km} / \mathrm{h}$ forward speed with the seed plate (1) for planting cotton seeds under Egyptians conditions.

-Though vacuum precision planter saves a lot of time and cotton seeds, the mechanical sowing operation of cotton seed should only be executed with chemically delinted seeds.

\section{REFERENCES}

1. Arzu, Y. and D. Adnan. 2007. Optimisation of the seed spacing uniformity performance of a vacuum-type precision seeder using response surface methodology. Biosystems Engineering. 97 (3 ):347-356

2. ASAE standards 1994. Manual of Standards. Engineering Practices and Data. ASE, St Joseph.

3. Chhinnan, M.S., Young, J. H. and R.P. Rohrbach. 1975. Accuracy of seed spacing in peanut planting, Trans. ASAE., 18 (1): 828-831.

4. Deyong, Y., Jianping, H., Junchao, Y., and Zuqing, X.,2010, World Automation Congress (WAC).

5. Hallikeri, S.S., Halemani, H.L., Patil, V.C., Palled, Y.B., Patil, B.C and Katageri,I.S. 2008. Effect of sowing time, Nitrogen and irrigation levels on yield, Fibre quality and CRY protein concentration in Bt-cotton. Unpublished Ph. D. Thesis. College of Agric, Dharwad Uni.

6. Kachman, S. D. and J. A. Smith. 1995. Alternative measures of accuracy in plant spacing for planters using single seed metering , Trans.of the ASAE., 28 (2): 379387

7. Karayel, D. and A . Özmerzi. 2002. A research on the use of a precision vacuum seeder unit for hill-drop sowing. Eighth International Congress on Mechanizations and Energy in Agriculture. Izmir, Turkey, 351-355, kusadasi -Turkey

8. Karayel, D. and A. Özmerzi. 2004. Effect of Forward Speed on Hill Dropping Uniformity of a Precision Vacuum Seeder. HortTechnology 14 (3):364-367 
9. Karayel, D., Barut, Z. and A. Ozmerzi. 2004. Mathematical modeling of vacuum pressure on a precision seeder. Biosystems Engineering. 87 (4):437-444

10. Manimehalai,N and R. Viswanathan.2006. Physical Properties of Fuzzy Cottonseeds. Bio-systems Engineering, 95(2): 207-217.

11. Mohsenin, N.N. 1986. Physical properties of plant and animal materials, Gordon and Breach Science Pub., N.Y.: 103-105.

12. Oida, A.1997. Using personal computer for agriculture machinery management. Kyoto Univ. JICA Pub

13. Özarslan, C. 2002. Physical Properties of Cotton Seed. PH-Post harvest Technology.

14. Ryu,I.H.and K.U.Kim.1998. Design of roller type metering device for precision planting. Trans. Amer. Soc. Agr. Eng. 41(4):923-930.

15. Sheikh, A and A. Gadir. 2004. Evaluation of mechanical sowing of medium staple cotton seed. Annual Report, Agricultural Engineering Research Programme, ARTC, Wad Medani.

16. Singh, R. C., G. Singh and D. C. Saraswat 2005. Optimization of design and operational parameters of a pneumatic seed metering device for planting cotton seeds. Bio-systems Engineering, 92(4): 429-438. 


\section{تطوير وتصميم وتصنيع جهاز تلقيم لآله زراعة دقيقة تناسب زراعة القطن المصرى} يسرى عبد القوى شعبان الصياد

قسم جحوث نظم ميكنة العطليات الزراعية - معهز بحوث العندسة الزراعية - مركز البحوث الزراعبة

تهدف هذه الدراسة إلى تطوير وتصنيع واختبار جهاز تلقيم لآلة زراعة دقيقة لبذور القطن تعمل

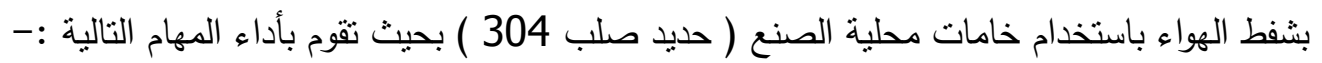
1-زراعة أكثر من بذرة فى الجورة الواحدة .

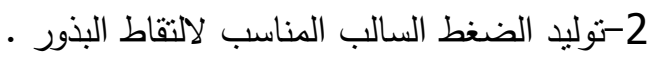
3-وضع البذور على العمق والمسافة المناسبين . 4-تغطيه البذور وكبس التربة . 5-إعطاء الكثافة النباتية المنلى لوحده المساحة . 6-يمكن استخدامها بأدنى تكلفة لزراعة الفدان .

وللوصول إلى هذا الهدف فقد تم تصميم وتصنيع جهاز تلقيم من خامات محلية ( حديد صلب 304 ) مانى وتم اختباره تحت عوامل التتغيل الآتية :-

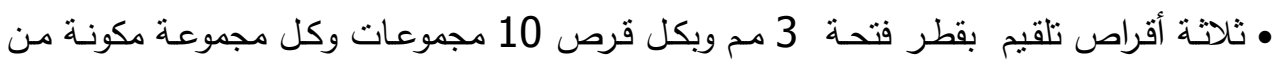

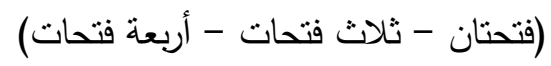

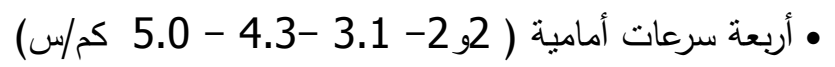

وكانت أهم النتائج المتحصل عليها ما يلى :

1-أعطى قرص التلقيم الأول ذوعدد 2 فتحة أقل فرق بين المسافة النظرية للبذور والمسافة الفعلية

$$
\text { لها عند } 3.1 \text { كم /ساعة (سرعة أمامية) }
$$

2-أعطى قرص التلقيم الأول (2-3) بذرة /الجورة بينما أعطى قرص التلقيم الثانى (3-4) بذرة

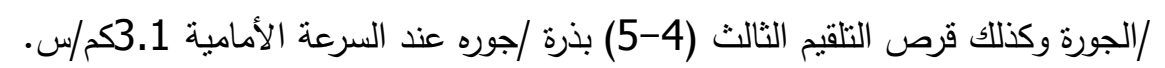
3-كانت أقل قيمة لـ seed miss index عند سرعة أمامية 3.1-2.2 كم/ س وذلك باستخدام

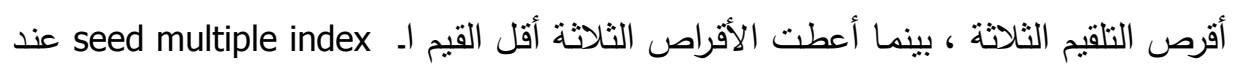

$$
\text { عند نفس السرعات. }
$$

4- أعلى قيمة لـ quality of feed index كانت عند سرعة أمامية 3.1 كم / س وذلك باستخدام

$$
\text { قرص التلقيم الثانى. }
$$

5-أعطى قرص التلقيم الأول أقل قيمة لـ precision in spacing عند سرعة أمامية 3.1 كم/س 
6-أعطى جهاز التلقيم المطور انتظامية لتوزيع النباتات على طول الخط لم تتجاوز 30\% وذلك باستخدام أقرص الثلقيم الثلاثة عند السرعات الأمامية المختلفة.

7-كانت تكلفة زراعة الفدان (جنيـ/ فدان) لآلة الزراعة المطورة تقل بحوالى 65\% وذلك عند مقارنتها بالزراعة اليدوية.

8-وتوصى الدراسة أن أنسب ظروف لتتغيل جهاز التلقيم المطور كانت باستخدام قرص التلقيم

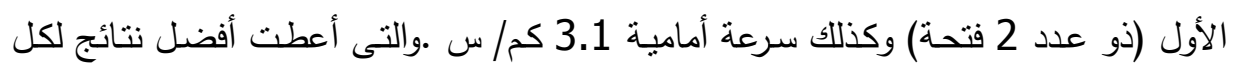

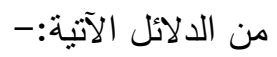

Seed miss index, seed multiple index, quality of feed index and precision in spacing 